\begin{tabular}{l|c|l}
\hline \hline Biological and & Vol. 6(1): 1-13, 2022 & $\begin{array}{l}\text { ISSN: 2002-6153 } \\
\text { Biol. Appl. Environ. Res. } \\
\text { www.baerj.com } \\
\text { editor@a baerj.com }\end{array}$ \\
\hline
\end{tabular}

\title{
Comparison of Some Biological Parameters between Young Grass Carp, Ctenopharyngodon idella (Valenciennes, 1844) fed on Artificial Diet and Alfalfa in Earthen Ponds at Basrah, Iraq
}

\author{
Sadiq J. Muhammed ${ }^{1}$, Adel Y. Al-Dubakel ${ }^{1 *}$ \& Ali I. Gowdet ${ }^{2}$ \\ ${ }^{1}$ Aquaculture Unit, Department of Fisheries and Marine Resources, College of Agriculture, \\ University of Basrah, Iraq \\ ${ }^{2}$ Department of Fisheries and Marine Resources, College of Agriculture, University of \\ Basrah, Iraq \\ *Corresponding author: aaldubakel22@gmail.com
}

\begin{abstract}
The current study aims to compare the relationships of some biological parameters of young grass carp, Ctenopharyngodon idella (Valenciennes, 1844) fed on artificial diet and alfalfa in earthen ponds. These parameters included length-weight relationship, relative length and weight of the alimentary canal, condition factor and survival rate. Results of lengthweight relationship showed that no significant differences $(P>0.05)$ were recorded for the t-test for the ideal value of 3 for fishes fed on artificial diet or alfalfa plant. The condition factor of young grass carp fed on artificial diet ranged between 0.021 to 1.074 , while for fishes fed on alfalfa plant was 0.023 to 1.270 for allometric and Fulton's condition factor, respectively. Also, there was no significant difference $(\mathrm{P}>0.05)$ for fishes fed on both diets in all biological parameters, the relative length of the alimentary canal for fishes fed on artificial diet (1.65) and on alfalfa plant (1.69), while the relative weight of the alimentary canal were 0.0285 and 0.0218 for fishes fed on both diets, respectively. Results also showed that the Zihler coefficient were 7.43 and 7.62 , respectively. The survival rate was $100 \%$ for both treatments.
\end{abstract}

Keywords: Condition factor, Length-weight relationship, Grass carp, RGL, RGM, ZI

\section{Introduction}

The grass carp is a species of the carp family Cyprinidae and its genus Ctenopharyngodon includes only one species (Chilton \& Muoneke, 1992), but in 2018, this fish was transferred from the carp family and included in the family Xenocyprididae (Tan \& Arbrumster, 2018). The grass carp, C. idella is considered as number one for aquaculture in the world since 2014, which has the ability to withstand various environmental conditions, as well as the ease of cultivation and the availability of nutritional requirements. Its acceptance by the consumer had led to the success of its cultivation on a large scale, so, the global production of grass carp reached 10500 tons in 2018 ( $\mathrm{Ni}$ et al., 2018; FAO, 2020). 
The study of length-weight relationship is of paramount importance in the field of fish biology, as through this relationship, it is possible to know the health of fishes and it is important in the field of fisheries (Oliveira et al., 2020). Through this relationship and by using mathematical relationships, weight can be predicted in terms of length or vice versa in fish populations, as well as the history of the fish life and changes that occurred in fish communities and thus their importance demonstrated in the management and exploitation of fish populations (Mortuza \& Almisned, 2013, 2015). Dhanze \& Dhanze (1997) studied the length-weight relationship of grass carp under the agro climatic zone of Himachal Pradesh. Wanner \& Klumb (2009) studied the length-weight relationship and condition factor of three Asian carps in the Missouri River, while Riberio et al. (2015) studied the length-weight relationship of $C$. idella fed on artificial diet, vegetable diet and mixed diet. Chitrakar \& Parajuli (2017) showed that the relationship of length and weight of grass carp is important in the management of fish farming, which enables fish workers to know many things such as size, age and composition of the fish community as well as the health of the fishes, and that the relationship of length and weight in the same species may differ in fish populations because of feeding and fishing.

Gut morphology and trophic level in fishes are closely related. Relative gut length (RGL) is usually correlated with fish diet (Geevarghese, 1983; Elliott \& Bellwood, 2003; Karachle \& Stergiou, 2010).

The condition factor $(\mathrm{K})$ is widely used in the field of fisheries and fish life studies. It indicates the health and fatness of fishes and the appropriate environmental conditions for the growth of fishes (Mortuza \& Almisned, 2013).

The current study aims to compare some biological parameters in young grass carp fed on artificial diet and alfalfa in earthen ponds at Basrah Province.

\section{Materials and Methods \\ Study Site}

The experiment was done in the earthen ponds of the Aquaculture Unit, which is located at the Agricultural Research and Experiments Station (College of Agriculture, University of Basrah). The station is located in the district of AlHartha, north of Basrah $\left(30^{0} 65^{\prime} 64.6^{\prime \prime} \mathrm{N}, 47^{0} 74^{\prime} 79.5^{\prime \prime} \mathrm{E}\right)$. The station contains four ponds, the area of each one is $2500 \mathrm{~m}^{2}$ besides 14 small ponds $\left(600 \mathrm{~m}^{2}\right.$ each $)$.

\section{Environmental Factors}

Some environmental factors (temperature, $\mathrm{pH}$, salinity and dissolved oxygen) were measured by using a digital device of the type Lovibond Senso Direct 150.

\section{Fishes and Experimental Ponds}

Small ponds $\left(600 \mathrm{~m}^{2}\right)$ were used with a water depth of 1.5 meters. Six ponds were drained entirely for 10 days till complete dryness before the experiment started. Then, they were filled with fresh water and left for several days for the purpose of developing the natural food. The source of water was from one of the 
branches of Shatt Al-Arab River. The experimental ponds were provided with screens at the water inlet and outlet pipes to prevent the escape of the experimental fishes and to prevent access of alien organisms.

Young grass carp $(6.3 \pm 0.28 \mathrm{~g})$ were transported from Dhi Qar Province on 7 July 2019 to the Marine Science Center ponds. After seven days, they were transferred to the experimental ponds and distributed at a density of $1 \mathrm{fish} / \mathrm{m}^{2}$ in each pond. Three replicates for each of the artificial diet and the alfalfa plant were used. On 26 July 2019, a random sample of about 100 fishes from each pond was taken by using a seine net for measuring length and weights before starting the experiment. After the end of the experiment (10 Dec. 2019), ponds were drained entirely, and all fishes were counted and a subsample for length and weight were determined.

\section{Feeding Management}

The daily feed quantity was calculated in respect to the total live fish weight in each pond, as fishes in ponds 1, 2 and 3 were fed on artificial diet (5\% BW/day) which was manufactured in the Feed Production Plant of the Agricultural Advisory Office belongs to the College of Agriculture, University of Basrah (Table 1).

Fishes in ponds 4, 5 and 6 were fed with the alfalfa plant (50\% BW/day), which was achieved from local markets. Because the fishes were small in size at the start of the experiment and were incapable to consume all parts of alfalfa, the process of cutting the plant was carried out by using an electric cutting machine designed for this purpose, until the fishes reached a size enable them to eat all the parts of the plant.

The daily feed ration for each treatment was divided into three equal meals; the first fed in the morning, the second in the midday and the third in the afternoon. Meals were manually distributed throughout the experiment period. The measurement of fish weight was repeated every 20 days, as the daily feed quantity was adjusted on the basis of the new weight of the fishes.

Table 1: Ingredients and proximate composition of the artificial diets.

\begin{tabular}{|l|c|c|c|}
\hline \multicolumn{1}{|c|}{ Ingredients } & $\%$ & \multicolumn{2}{c|}{ Chemical analysis (\%) as dry matter } \\
\hline Fish meal & 20 & Moisture & $9.67 \pm 0.58$ \\
\hline Wheat flour & 35 & Crud protein & $27.12 \pm 0.82$ \\
\hline Wheat bran & 23 & Crud lipid & $6.11 \pm 2.47$ \\
\hline Soybean meal & 20 & Ash & $7.61 \pm 0.54$ \\
\hline $\begin{array}{l}\text { Vitamins and mineral } \\
\text { premix }\end{array}$ & 2 & Carbohydrates & $46.82 \pm 2.35$ \\
\cline { 3 - 4 } & & Total energy (Kcal/kg) & $4272.50 \pm 60.10$ \\
\hline
\end{tabular}

\section{Measuring Biological Parameters Length-Weight Relationship}

To calculate the length-weight relationship, the formula of Le Cren (1951) was used to estimate the relationship between the weight $(\mathrm{g})$ of the fish and its total length $(\mathrm{cm})$, by using the linear regression of the equation: $\mathrm{W}=a \mathrm{~L}^{\mathrm{b}}$ where $\mathrm{a}$ and $\mathrm{b}$ are the coefficients, $\mathrm{L}$ is the total length $(\mathrm{cm})$ and $\mathrm{W}$ is the wet weight $(\mathrm{g})$. 


\section{Condition Factor}

Fulton's condition factor was calculated as $\mathrm{K}_{\mathrm{f}}=100 \times \mathrm{W} / \mathrm{L}^{3}$

Allometric condition factor was calculated as $\mathrm{K}_{\mathrm{a}}=\mathrm{W} / \mathrm{L}^{\mathrm{b}}$

Relative condition factor was calculated as $\mathrm{K}_{\mathrm{n}}=\mathrm{W} / \mathrm{aL}^{\mathrm{b}}$

Fulton's condition factor was calculated according to Froese (2006) and both allometric condition and relative condition factors were calculated according to Le Cren (1951).

\section{Gut Parameters}

The alimentary canal of each fish was removed from the body and gut was then uncoiled to measure gut length (GL) to the nearest centimeter. After emptying the contents of the alimentary canal for measuring its weight to the nearest $0.5 \mathrm{~g}$, the gut parameters were calculated according to Zihler (1981) and German \& Horn (2006) as in the followings:

Relative gut length $(\mathrm{RGL})=$ gut length in $\mathrm{cm} /$ standard length in $\mathrm{cm}$

Relative gut mass $(\mathrm{RGM})=$ gut mass in $\mathrm{g} /$ body mass in $\mathrm{g}$

Zihler's Index $(\mathrm{ZI})=$ gut length in $\mathrm{mm} / 10 \mathrm{x}$ (body mass in $\mathrm{g})^{1 / 3}$

$$
\begin{aligned}
& \text { Number of fishes alive } \\
& \text { Survival Rate (SR) = ------------------------ x } 100
\end{aligned}
$$

\section{Statistical Analysis}

One-way analysis of variance (ANOVA) was used to test all parameters. This statistical analysis was accomplished with the computer software SPSS package Version 22.

\section{Results}

\section{Environmental Factors}

The values of environmental factors during the experiment period (Table 2) showed that water temperature was the most mutable factor. The highest temperature $\left(27.2^{\circ} \mathrm{C}\right)$ was recorded during July and the lowest temperature $(18.7$ ${ }^{\circ} \mathrm{C}$ ) was during December. $\mathrm{pH}$ value in December was 7.5 and in November reached 8.4. Water salinity fluctuated from 4.8 psu in September to 9.3 psu in July. Dissolved oxygen was in its highest level $(7.5 \mathrm{mg} / \mathrm{l})$ in December, while the lowest level was $6.4 \mathrm{mg} / \mathrm{l}$ in August. 
Table 2: Environmental parameters during the experimental period.

\begin{tabular}{|l|l|l|l|l|}
\hline Period & Temp. $\left({ }^{\circ} \mathrm{C}\right)$ & $\mathrm{pH}$ & Salinity $(\mathrm{psu})$ & $\mathrm{DO}(\mathrm{mg} / \mathrm{l})$ \\
\hline 27 July & 27.2 & 8.1 & 9.3 & 6.7 \\
\hline 15 Aug. & 25.9 & 7.9 & 6.3 & 6.4 \\
\hline 3 Sep. & 26.1 & 8.1 & 4.8 & 6.8 \\
\hline 25 Sep. & 26.6 & 7.8 & 5.1 & 6.7 \\
\hline 17 Oct. & 23.6 & 8.1 & 5.6 & 7.1 \\
\hline 9 Nov. & 19.6 & 8.4 & 5.6 & 6.9 \\
\hline 10 Dec. & 18.7 & 7.5 & 5.1 & 7.5 \\
\hline
\end{tabular}

\section{Length-Weight Relationships}

Figure 1 represents the relationship between length and weight of young grass carp before the experiment. As the value of $b$ was equal to 2.3085 , this value represented significant differences $(\mathrm{P} \leq 0.05)$ for the t-test from the ideal value of 3 , while the coefficient of determination (R2) was $83.54 \%$. Figure 2 represents the length-weight relationship of grass carp fed on artificial diet. The value of $b$ equals to 1.971. This value indicated significant differences $(\mathrm{P}>0.05)$ for the $\mathrm{t}$-test from the ideal value of 3 . The coefficient of determination (R2) was $0.56 .20 \%$. As for the treatment of grass carp fed on alfalfa plant, the value of $b$ was 2.5563. Also, this value indicated significant differences $(\mathrm{P}>0.05)$ for the t-test for the ideal value of 3 , while the coefficient of determination (R2) equaled $78.73 \%$ (Figure 3 ).

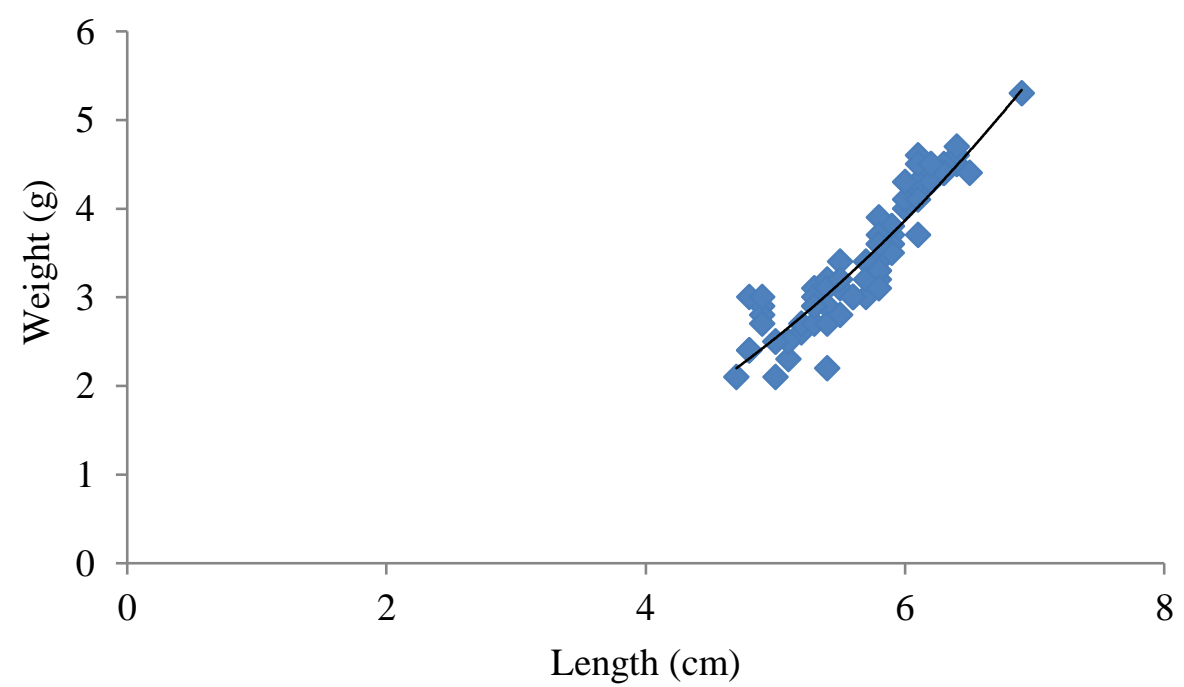

Figure 1: Regression curve of length-weight relationship of young grass carp before experiment. $\mathrm{a}=0.0618, \mathrm{~b}=2.3085, \mathrm{R}^{2}=83.54 \%$ and $\mathrm{n}=100$. 


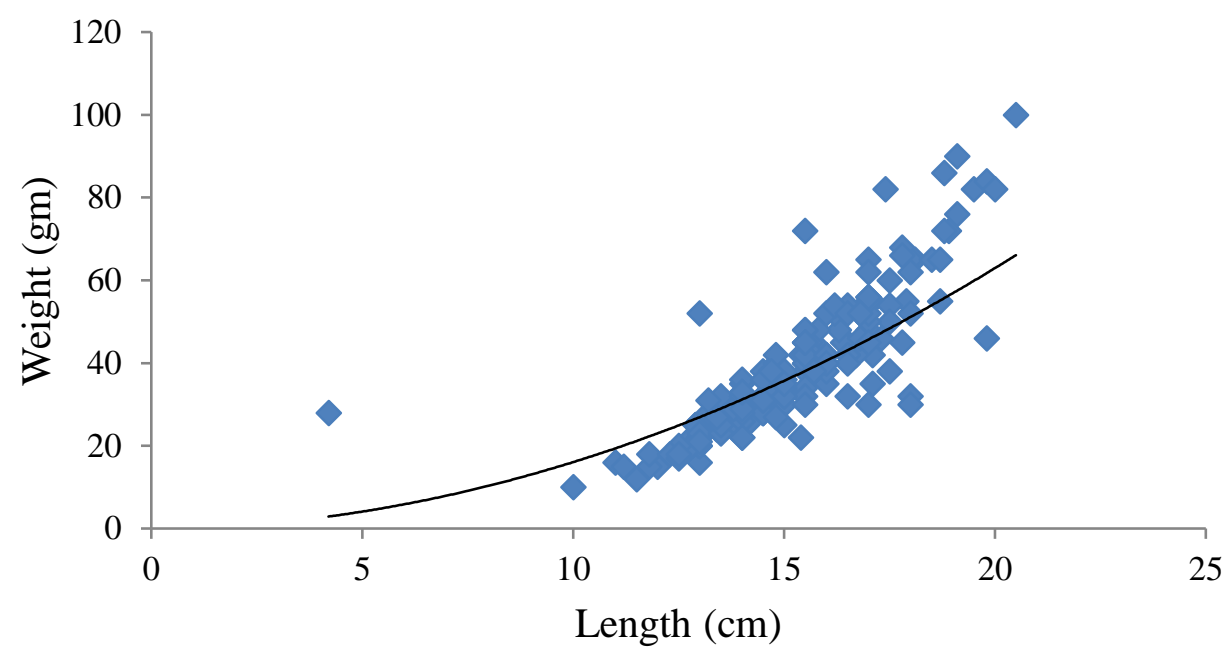

Figure 2: Regression curve of length-weight relationship of young grass carp fed artificial diet. $\mathrm{a}=0.1716, \mathrm{~b}=1.971, \mathrm{R}^{2}=56.20 \%$ and $\mathrm{n}=184$.

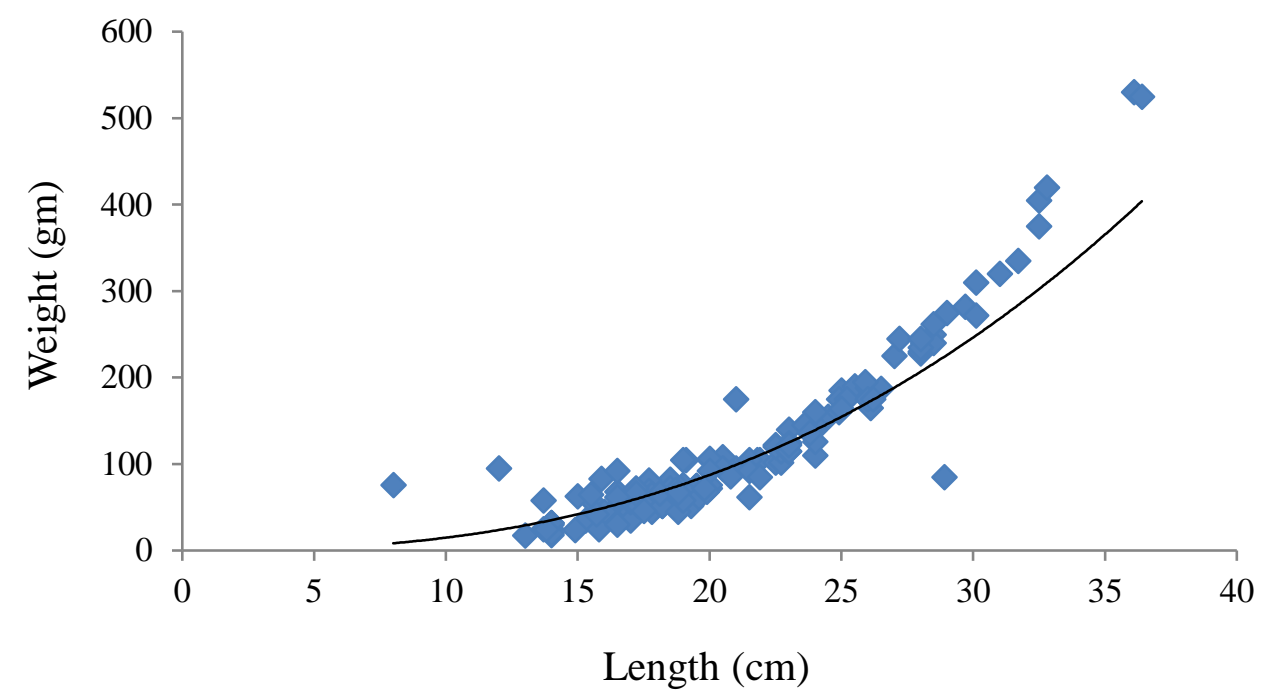

Figure 3: Regression curve of length-weight relationship of young grass carp fed alfalfa plant. $a=0.0413, b=2.5563, R^{2}=78.73 \%$ and $n=180$.

\section{Condition Factor}

Table 3 showed values of three condition factor formulas of young grass carp before and after the experiment. It was noticed that the fishes fed on the artificial diet had a condition factor value less than fishes fed on alfalfa plant, while values of $\mathrm{Kf}$ and Ka before experiment were higher from both treatments. The results of the statistical analysis showed that there were no significant differences $(\mathrm{P}>0.05)$ between both treatments in all condition factor formulas, while only values of $\mathrm{Kf}$ and $\mathrm{Ka}$ of grass carp before experiment differ significantly $(\mathrm{P} \leq 0.05)$ with values after experiment. 
Table 3: Total body length and weight, average weight gain and condition factor of young grass carp before and after the experiment (Mean \pm SD).

\begin{tabular}{|c|c|c|c|c|}
\hline \multirow{3}{*}{\multicolumn{2}{|c|}{ Parameters }} & \multicolumn{3}{|c|}{ Treatment } \\
\hline & & \multirow[t]{2}{*}{ Before experiment } & \multicolumn{2}{|c|}{ After experiment } \\
\hline & & & Artificial diet & Alfalfa plant \\
\hline \multicolumn{2}{|l|}{ Number of fishes } & 100 & 184 & 180 \\
\hline \multirow{2}{*}{ Total length $(\mathrm{cm})$} & Min. & 4.2 & 4.7 & 8.0 \\
\hline & Max. & 6.9 & 20.5 & 36.4 \\
\hline \multirow{2}{*}{ Body weight (g) } & Min. & 2.1 & 10.0 & 17.5 \\
\hline & Max. & 5.3 & 100.0 & 530.0 \\
\hline \multicolumn{2}{|c|}{ Average weight gain (gm) } & & 6.74 & 15.29 \\
\hline \multicolumn{2}{|c|}{$\mathrm{Kf}$} & $1.873^{\mathrm{a}} \pm 0.21$ & $1.074^{\mathrm{b}} \pm 0.054$ & $1.145^{\mathrm{b}} \pm 0.148$ \\
\hline \multicolumn{2}{|l|}{$\mathrm{Ka}$} & $0.064^{\mathrm{a}} \pm 0.019$ & $0.021^{\mathrm{b}} \pm 0.001$ & $0.023^{\mathrm{b}} \pm 0.003$ \\
\hline \multicolumn{2}{|l|}{$\mathrm{Kn}$} & $1.004^{\mathrm{a}} \pm 0.091$ & $1.056^{\mathrm{a}} \pm 0.058$ & $1.046^{\mathrm{a}} \pm 0.144$ \\
\hline
\end{tabular}

Data with different superscripts are significantly different $(\mathrm{P}<0.05)$.

$\mathrm{Kf}=$ Fulton's condition factor, $\mathrm{Ka}=$ Allometric condition factor and $\mathrm{Kn}=$ Relative condition factor.

\section{Gut Parameters}

Average relative gut length (RGL) and Zihler's Index (ZI) showed that there was no significant difference $(\mathrm{P}>0.05)$ between young grass carp fed artificial diet $(1.65,7.43)$ and alfalfa plant $(1.69,7.62)$, respectively, while relative gut mass $(\mathrm{RGM})$ showed significant differences $(\mathrm{P} \leq 0.05)$ between artificial diet $(0.0285)$ and alfalfa plant (0.0218) as in in Table 4. In both treatments, survival rates were $100 \%$.

Table 4: Gut parameters and survival rate of young grass carp fed artificial diet and alfalfa plant (Mean \pm SD).

\begin{tabular}{|l|c|c|}
\hline \multicolumn{1}{|c|}{ Parameters } & Artificial diet & Alfalfa plant \\
\hline Relative gut length (RGL) & $1.65^{\mathrm{a}} \pm 0.25$ & $1.69^{\mathrm{a}} \pm 0.06$ \\
\hline Relative gut mass (RGM) & $0.0285^{\mathrm{a}} \pm 0.0025$ & $0.0218^{\mathrm{b}} \pm 0.0033$ \\
\hline Zihler's Index (ZI) & $7.43^{\mathrm{a}} \pm 1.05$ & $7.62^{\mathrm{a}} \pm 0.22$ \\
\hline Survival rate (\%) & $100^{\mathrm{a}}$ & $100^{\mathrm{a}}$ \\
\hline
\end{tabular}

Data with different superscripts are significantly different $(\mathrm{P}<0.05)$.

\section{Discussion}

The relationship of length and weight is of great importance in the field of fish life. It helps to know growth, mortality and reproduction (Moutopoulos \& Stergiou, 2002; Naeem \& Salam, 2004). Its deviation from the standard value means that the increase occurs in the direction of length or weight at the expense of the other, and thus, the growth in it is non-standard (Bagenal \& Tesch, 1978). Results of the current study showed that growth is negative allometric before experiment and after the experiment, the growth in both treatments. This result is different from that of Riberio et al. (2015) who recorded the existence of significant differences in this relationship for different treatments of grass carp in ponds. 
Results of the current study is coincided with Taher (2020) who indicated that growth is negative allometric before and after the experiment. Moreover, the results of the current study is different from both Bhosale \& Bhilave (2014) and Chitrakar \& Parajuli (2017) of grass carp in that the growth in both these two studies was positive allometric with the artificial diet, while it was negative in the current study. The value of slope (b) may be deviated from the "ideal value" of 3 which represents an isometric growth (Ricker \& Carter, 1958) because of certain environmental conditions or factors related to the fish themselves. When $b$ is less than 3 , fishes become slimmer with increasing length, and growth will be negatively allometric. But when $b$ is greater than 3, fishes become heavier, showing a positive allometric which reflecting optimum conditions for growth.

Condition factor is an important life measure that is useful in knowing the suitability of the water for fish growth and is used as an indicator of growth, nutritional density and health status of fishes (Le Cren, 1951). The results of the current study indicated that the Fulton's condition coefficient for both treatments was $>1$. This is an evidence of the suitability of the environment for the growth of this species. This corresponds to Chitrakar \& Parajuli (2017), while Kristan et al. (2018) recorded a value 0.90 of condition coefficient. The current study recorded a lower condition coefficient than what was recorded by Abbas et al. (2014) when comparing it to the condition coefficient of thaila (Catla catla), rohu (Labeo rohita) and common carp (Cyprinus carpio), as it recorded a condition coefficient of 3.4, 2.72 and 2.77 , respectively.

Results of the present study is similar to that of Riberio et al. (2015) with no significant differences for the condition coefficient between the different treatments. Nekoubin \& Sudagar (2012) recorded a condition coefficient for jet plant of 0.9 and processed a ration of 0.8 , which is less than what is recorded in the current study. Result of the current study is coincided with Nekoubin \& Sudgar (2012) who showed that grass carps prefer plant rations over other rations. Choi et al. (2016) studied the growth of grass carps on food waste and commercial diets in Hong Kong and found that grass carps prefer plant-based proteins over animalsource proteins, the use of carbohydrates as an energy source instead of fat, and that the high percentage of fat in the diet leads to reduce the growth and accumulation of fat in fish tissues.

The survival rate in the current study was $100 \%$ for all treatments. This is consistent with Devaraj et al. (1986), Cremer et al. (2005), Al-Shkakrchy \& Ahemed (2013) and Taher (2017), but it differed with other studies such as Toutou et al. (2018) who recorded a survival rate of $81.69 \%$, while Nekoubin \& Sudgar (2012) found, by using three diets; plants, manufactured and commercial feeds, that the survival rate was 53.77, 89.12 and $40.18 \%$, respectively. Hossain et al. (2020) found that the survival rate of grass carp fed on plants was higher than that fed on manufactured ration.

In general, the relative length of the alimentary canal (RGL) reflects the nature of feeding in fishes. If RGL is $<1$, then the fishes are carnivorous, if it is $<3$, then they are omnivorous feeding and if RGL is $>3$, then they are herbivorous (Ward- 
Campell et al., 2005). The results of the current study showed that there were no significant differences in the relative length of the alimentary canal of fishes fed on artificial diet and alfalfa plant. This matched with Hama et al. (2019), in which it was demonstrated that adding alfalfa powder to the diet did not affect the length or weight of the alimentary canal in common carp. From the RGL values recorded in the current study, it was found that grass carps are omnivorous. It is known that grass carps are herbivorous, but this is in larger sizes of fishes compared with the small sizes used in the current study. This conclusion is in agreement with Day et al. (2011), in which they showed that some fishes do not eat plants, not because of their alimentary canals, but because of the mechanism of the mouth and pharynx. White (2013) showed that many fishes start their lives as omnivorous feeding and then turn to herbivorous feeding. White (2013) recorded relative length of the alimentary canal in the small marine fishes feeding (0.54) less than what was recorded in the present study. Grass carps in the beginning of the experiment could not eat the alfalfa plant before the process of cutting and chopping it. This is in agreement with Hemlata et al. (2016) where the plant Zizania latifolia was cut and smashed before feeding grass carps, as well as with Shireman \& Smith (1981) who showed that grass carps feed on wild plants prefer soft ones.

Statistical analysis of the average relative gut weight (RGM) for current experiment showed that there were significant differences $(\mathrm{P} \leq 0.05)$ between both treatments. However, German \& Horn (2006) did not noticed any significant differences in the value of the relative gut weight between carnivorous and herbivorous fishes.

Results of the statistical analysis showed that there were no significant differences in the values of Zihler's Index (ZI) for grass carps fed on artificial diet and alfalfa plant, in spite, it was highest in fishes fed on alfalfa plant. German \& Horn (2006) recorded ZI value of 0.49 , which is less than values of the current study. The reason is may be due to variations of species and fish size compared to the present study.

In conclusion, the present study points out the importance of alfalfa plant for feeding young grass carps, especially in ponds, as well as its effect on biological parameters compared to artificial diets. This importance may be useful in the production of future culture projects. Artificial diets could be used for large sized fishes as the development of their alimentary canal is completed.

\section{Acknowledgements}

The investigators sincerely thank the staffs of the Agricultural Researches and Experiment Station for their efforts and help throughout the cultivation and to accomplish the field sampling as well as for providing equipment to accomplish this experiment.

\section{References}

Abbas, S.; Ashraf, M. \& Ahmed, I. (2014). Effect of fertilization and supplementary feeding on growth performance of Labeo rohita, Catla catla 
and Cyprinus carpio. J. Anim. Plant Sci., 24(1): 142-148. http:// thejaps.org.pk/ocs/v-24-1/21.pdf.

Al-Shkakrchy, S.S. \& Ahemed, H.A. (2013). Test duckweed Lemnas spp. as a potential food for grass carp Ctenopharyngodon idella and common carp Cyprinus carpio L. Al-Anbar J. Vet. Sci., 6(1): 44-55. https://www.iasj.net/ iasj/download/147cc21fad7e9574.

Bagenal, T.B. \& Tesch, F.W. (1978). Age and growth. In: Bagenal, T.B. (ed.). Methods for assessment of fish production in fresh waters. $3^{\text {rd }}$ edition. IBP Handbook No., 3, Blackwell Sci. Publ., Oxford: 101-136.

Bhosale, S.V. \& Bhilave, M.P. (2014). Gross conversion efficiency of Ctenopharyngodon idella fed with conventional and combinations of formulated feed. Res. J. Agric. Sci., 5(5): 939-942.

Chilton, E.W. \& Muoneke, M.I. (1992). Biology and management of grass carp (Ctenopharyngodon idella, Cyprinidae) for vegetation control: A North American perspective. Rev. Fish Biol. Fish., 2: 283-320. DOI:10.1007/ BF00043520.

Chitrakar, P. \& Parajuli, K. (2017). Length and weight relationship studies of alimentary canal compared to the total body weight of grass carp Ctenopharyngodon idella (Valenciennes, 1844) at Balkhu live fish market of Kathmandu, Nepal. Int. J. Fish. Aquat. Stud., 5(6): 185-190. https://www. fisheriesjournal.com/archives/2017/vol5issue6/PartC/5-6-16-871.pdf.

Choi, W.M.; Lam, C.L.; Mo, W.Y. \& Wong, M.H. (2016). The use of food wastes as feed ingredients for culturing grass carp (Ctenopharyngodon idellus) in Hong Kong. Environ. Sci. Pollut. Res., 23: 7178-7185. DOI:10.1007/s11356015-5465-8.

Cremer, M.C.; Enhua, Z. \& Jian, Z. (2005). Grass carp exhibit excellent growth and feed conversion on cost efficient, soy-based diet 55. https://ussec.org/wpcontent/uploads/2019/10/2014-harbin-carp-fingerling-trial-result-publication.

Day, R.D.; German, D.P. \& Tibbetts, I.R. (2011). Why can't young fish eat plants? Neither digestive enzymes nor gut development preclude herbivory in the young of stomach less marine herbivorous fish. Comp. Biochem. Physiol., Part B Biochem. Mol. Biol., 158(1): 23-29. DOI:10.1016/j.cbpb.2010.09.010.

Devaraj, K.V.; Keshavappa, G.Y. \& Manissery, J.K. (1986). Growth of grass carp, Ctenopharyngodon idella Val., fed on two terrestrial fodder plants. Aquac. Res., 17(2): 123-128. DOI:10.1111/j.1365-2109.1986.tb00093.x.

Dhanze, R. \& Dhanze, J.R. (1997). Biology of scale carp and grass carp lengthweight relationship and growth performance under the Agro Climatic Zone of Himachal Pradesh. Indian J. Fish., 44: 255-263. http:// epubs.icar.org.in/ ejournal/index.php/IJF/article/view/8841/3712.

Elliott, J.P. \& Bellwood, D.R. (2003). Alimentary tract morphology and diet in three coral reef fish families. J. Fish Biol., 63(6): 1598-1609. DOI:10.1111/ j.1095-8649.2003.00272.x.

FAO (2020). The State of World Fisheries and Aquaculture. Sustainability in action. Rome: 206 pp. DOI:10.4060/ca9229en. 
Froese, R. (2006). Cube law, condition factor and weight-length relationships: History, meta-analysis and recommendations. J. Appl. Ichthyol., 22: 241-253. DOI:10.1111/j.1439-0426.2006.00805.x.

Geevarghese, C. (1983). Morphology of the alimentary tract in relation to diet among gobioid fishes. J. Nat. Hist., 17: 731-741. DOI:10.1080/ 00222938300770571.

German, D.P. \& Horn, M.H. (2006). Gut length and mass in herbivorous and carnivorous prickleback fishes (Teleostei: Stichaeidae): ontogenetic, dietary, and phylogenetic effects. Mar. Biol., 148(5): 1123-1134. DOI:10.1007/ s00227-005-0149-4.

Hama, S.A.; Abdulrahman, N.M.; Qader, K.O.; Maaruf, S.A. \& AbuBakir, S. (2019). Effect of adding alfalfa leaves powder on growth and health performance of common carp (Cyprinus carpio L.). J. Anim. Poult. Prod., Mansoura Univ., 10(8): 257-260.

Hemlata, H.; Singh, Kh.R. \& Devi, W.S. (2016). Studies on the growth of grass carp, Ctenopharyngodon idella (Cuvier and Val.) fed on amphibious plant Zizania latifolia under intensive fish culture. Int. J. Res. Sci. Innov., 3(4): 2831. http://rsisinternational.org/IJRSI/ Issue33/28-31.pdf.

Hossain, M.M.; Ali, M.L.; Khan, S.; Haque, M.M. \& Shahjahan, M. (2020). Use of Asian water grass as feed of grass carp. Aquac. Rep., 18: 1-7. DOI:10.1016/ j.aqrep.2020.100434.

Karachle, P.K. \& Stergiou, K.I. (2010). Gut length for several marine fish: Relationships with body length and trophic implications. Mar. Biodiv. Rec., 3: e106. https://www.academia.edu/9532996/.

Kristan, J.; Blecha, M. \& Policar, T. (2018). Survival and growth rates of juvenile grass carp Ctenopharyngodon idella overwintered in ponds and recirculating aquaculture systems including a comparison of production economics. Turk. J. Fish. Aquat. Sci., 19(3): 261-266. DOI:10.4194/1303-2712-v19_3_09.

Le Cren, E.D. (1951). The length-weight relationship and seasonal cycle in gonad weight and condition in the perch (Perca fluviatilis). J. Anim. Ecol., 20(2): 201-219. JSTOR, www.jstor.org/stable/1540.

Mortuza, M.G. \& Al-Misned, F.A. (2013). Length-weight relationships, condition factor and sex-ratio of Nile tilapia, Oreochromis niloticus in Wadi Hanifah, Riyadh, Saudi Arabia. World J. Zool., 8(1): 106-109. https://www.idosi.org/ wjz/wjz8(1)13/15.pdf.

Mortuza, M.G. \& Al-Misned, F.A. (2015). Length-weight relationships of twelve fishes from the River Padma near Rajshahi City, Bangladesh. Fish. Aquac. J., 6(1): 1-5. DOI:10.4172/2150-3508.1000113.

Moutopoulos, D.K. \& Stergiou, K.I. (2002). Length-weight and length-length relationships of fish species from the Aegean Sea (Greece). J. Appl. Ichthyol., 18(3): 200-203. DOI:10.1046/j.1439-0426.2002.00281.x.

Naeem, M. \& Salam, A. (2004). Morphometric studies on Oreochromis nilotica (male) in relation to body size from Islamabad, Pakistan. Punjab Univ. J. Zool., 19: 73-81. 
Nekoubin, H. \& Sudagar, M. (2012). Effect of formulate and plant diets on growth performance and survival rate of juvenile grass carp (Ctenopharyngodon idella). World J. Fish Mar. Sci., 4(4): 386-389. DOI:10.5829/ idosi.wjfms.2012.04.04.62143.

Ni, J.; Yan, Q.; Yu, Y. \& Zhang, T. (2018). Factors influencing the grass carp gut microbiome and its effect on metabolism. FEMS Microbiol. Ecol., 87(3): 704-714. DOI:10.1111/1574-6941.12256.

Oliveira, M.S.B.; Silva, L.M.A.; Prestes, L. \& Tavares-Dias, M. (2020). Lengthweight relationship and condition factor for twelve fish species from the Igarapé Fortaleza basin, a small tributary of the Amazonas River estuary. Acta Amazon., 50: 8-11. DOI:10.1590/1809-4392201900702.

Riberio, M.O.; Werle, S.; Scharnoski, E.M.; Castoldi, R. \& Noleto, R.B. (2015). A relação peso-comprimento e fator de condição para carpa capim (Ctenopharyngodon idella) submetida a diferentes dietas. Rev. Agron. Meio Ambiente, 8(2): 303-315. DOI:10.17765/2176-9168.2015v8n2p303-315. (English abstract).

Ricker, W.E. \& Carter, N.M. (1958). Handbook of computations for biological statistics of fish populations, No. 119. The Fisheries Research Board of Canada. Queen's printer and controller of stationary, Ottawa, $300 \mathrm{pp}$. https://waves-vagues.dfo-mpo.gc.ca/Library/10161.pdf.

Shireman, J.V. \& Smith, C.R. (1983). Synopsis of biological data on the grass carp, Ctenopharyngodon idella (Cuvier and Valenciennes, 1844). FAO Synopsis, 135: 86 pp. http://www.fao.org/3/ap938e/ap938e.pdf.

Taher, M.M. (2017). Laboratory experiments on cultivation of grass carp Ctenopharyngodon idella (Valenciennes, 1844). Basrah J. Agric. Sci., 30(2): 91-98. DOI:10.37077/25200860.2017.57.

Taher, M.M. (2020). Effects of fish density on growth and condition factor of grass carp, Ctenopharyngodon idella cultivated in earthen ponds. Marsh Bull., 15(2): 62-72.

Tan, M. \& Armbruster, J.W. (2018). Phylogenetic classification of extant genera of fishes of the order Cypriniformes (Teleostei: Ostariophysi). Zootaxa, 4476(1): 6-39. DOI:10.11646/zootaxa.4476.1.4.

Toutou, M.M.; Soliman, A.A.A.; Elokaby, M.A. \& Abdel-Rahim, M.M. (2018). Impacts of using fresh aquatic plants as a total substitute for formulated feed on performance, health and economic efficiency of grass carp Ctenopharyngodon idella (Valenciennes, 1844) fingerlings. AACL Bioflux, 11(6): 1892-1907. http://www.bioflux.com.ro/docs/2018.1892-1907.pdf.

Wanner, G.A. \& Klumb, R.A. (2009). Length-weight relationships for three Asian carp species in the Missouri River. J. Freshw. Ecol., 24(3): 489-495. DOI: $10.1080 / 02705060.2009 .9664322$.

Ward-Campbell, B.M.S.; Beamish, F.W.H. \& Kongchaiya, C. (2005). Morphological characteristics in relation to diet in five coexisting Thai fish species. J. Fish Biol., 67(5): 1266-1279. DOI:10.1111/j.1095-8649.2005. 00821.x. 
White, T.C.R. (2013). When is a herbivore not a herbivore? Oecologia, 67(4): 596597. DOI:10.1007/bf00790034.

Zihler, F. (1981). Gross morphology and configuration of digestive tracts of Cichlidae (Teleostei, Perciformes): Phylogenetic and functional significance. Neth. J. Zool., 32(4): 544-571. DOI:10.1163/002829682X00210. 